4

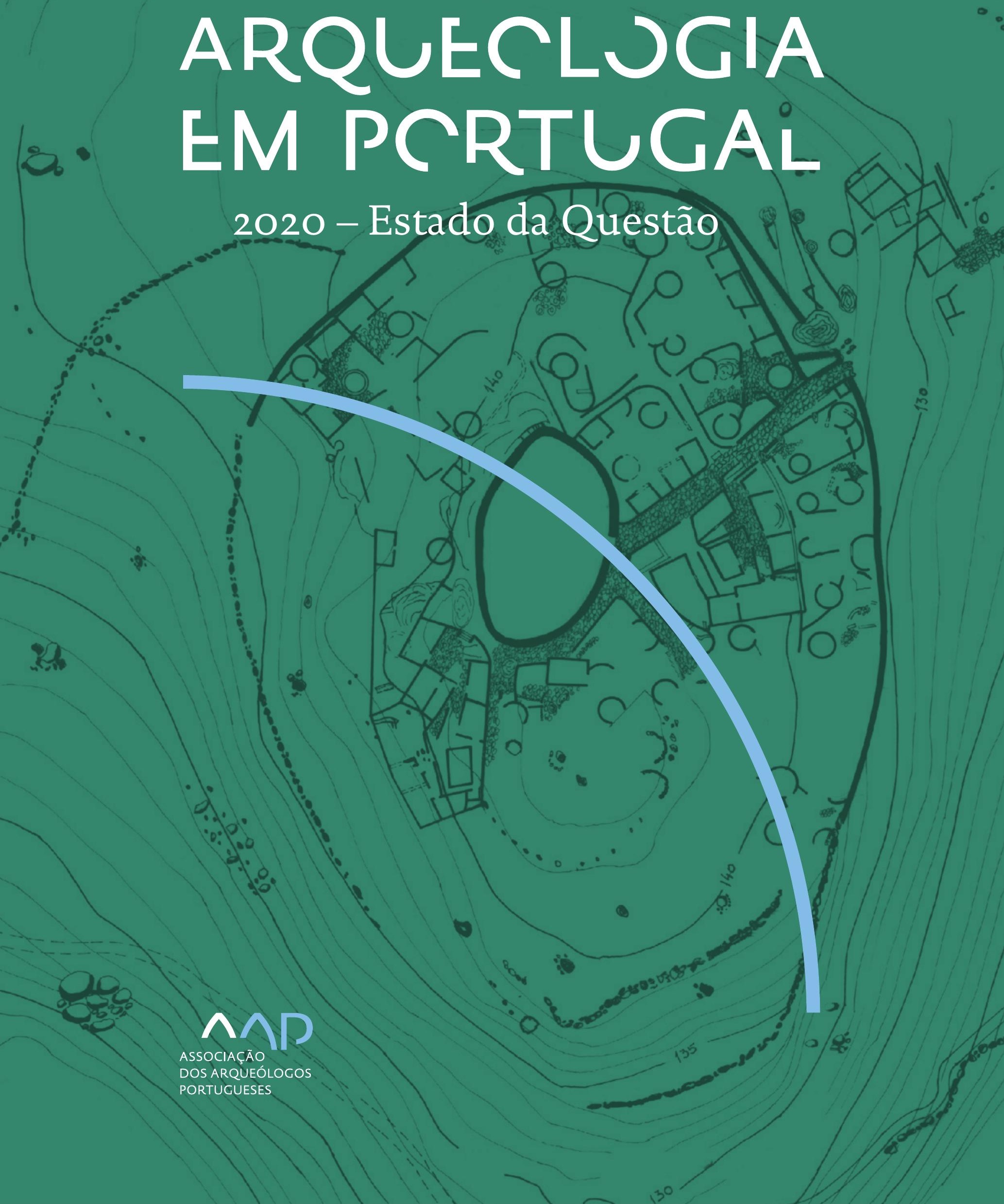


Coordenação editorial: José Morais Arnaud, César Neves e Andrea Martins Design gráfico: Flatland Design

AAP - ISBN: 978-972-9451-89-8

CITCEM - ISBN: 978-989-8970-25-1

Associação dos Arqueólogos Portugueses e CITCEM

Lisboa, 2020

O conteúdo dos artigos é da inteira responsabilidade dos autores. Sendo assim a Associação dos Arqueólogos Portugueses declina qualquer responsabilidade por eventuais equívocos ou questões de ordem ética e legal.

Desenho de capa:

Planta do castro de Monte Mozinho (Museu Municipal de Penafiel).

\section{$\hat{\wedge} \mathrm{P}$}

DOS ARQUEÓLOGOS PORTUGUESES

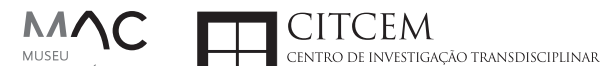
MUSEU
ARQUELLÓGICO
DO CARMO
U.PORTO

FLUP FACULDADE DE LETRAS
UNIVERSIDADE DO PORTO

Apoio

EC para a Ciência 


\section{Índice}

15 Prefácio

José Morais Arnaud

\section{Historiografia e Teoria}

17 Território, comunidade, memória e emoção: a contribuição da história da arqueologia (algumas primeiras e breves reflexões)

Ana Cristina Martins

25 Como descolonizar a arqueologia portuguesa?

Rui Gomes Coelho

41 Arqueologia e Modernidade: uma revisitação pessoal e breve de alguns aspetos da obra homónima de Julian Thomas de 2004

Vítor Oliveira Jorge

57 Dados para a História das Mulheres na Arqueologia portuguesa, dos finais do século XIX aos inícios do século XX: números, nomes e tabelas

Filipa Dimas / Mariana Diniz

73 Retractos da arqueologia portuguesa na imprensa: (in)visibilidades no feminino

Catarina Costeira / Elsa Luís

85 Arqueologia e Arqueólogos no Norte de Portugal Jacinta Bugalhão

101 Vieira Guimarães (1864-1939) e a arqueologia em Tomar: uma abordagem sobre o território e as gentes

João Amendoeira Peixoto / Ana Cristina Martins

115 Os memoráveis? A arqueologia algarvia na imprensa nacional e regional na presente centúria (2001-2019): características, visões do(s) passado(s) e a arqueologia

enquanto marca

Frederico Agosto / João Silva

129 A Evolução da Arqueologia Urbana e a Valorização Patrimonial no Barlavento Algarvio: Os casos de Portimão e Silves

Artur Mateus / Diogo Varandas / Rafael Boavida

\section{Gestão, Valorização e Salvaguarda do Património}

145 O Caderno Reivindicativo e as condições de trabalho em Arqueologia Miguel Rocha / Liliana Matias Carvalho / Regis Barbosa / Mauro Correia / Sara Simões / Jacinta Bugalhão / Sara Brito / Liliana Veríssimo Carvalho / Richard Peace / Pedro Peça / Cézer Santos

155 Os Estudos de Impacte Patrimonial como elemento para uma estratégia sustentável de minimização de impactes no âmbito de reconversões agrícolas Tiago do Pereiro

165 Salvaguarda de Património arqueológico em operações florestais: gestão e sensibilização Filipa Bragança / Gertrudes Zambujo / Sandra Lourenço / Belém Paiva / Carlos Banha / Frederico Tatá Regala / Helena Moura / Jacinta Bugalhão / João Marques / José Correia / Pedro Faria / Samuel Melro

179 Os valores do Património: uma investigação sobre os Sítios Pré-históricos de Arte Rupestre do Vale do Rio Côa e de Siega Verde José Paulo Francisco 
189 Conjugando recursos arqueológicos e naturais para potenciar as visitas ao Geoparque Litoral de Viana do Castelo (Noroeste de Portugal)

Hugo A. Sampaio / Ana M.S. Bettencourt / Susana Marinho / Ricardo Carvalhido

203 Áreas de Potencial Arqueológico na Região do Médio Tejo: Modelo Espacial Preditivo Rita Ferreira Anastácio / Ana Filipa Martins / Luiz Oosterbeek

223 Património Arqueológico e Gestão Territorial: O contributo da Arqueologia para a revisão do PDM de Avis

Ana Cristina Ribeiro

237 A coleção arqueológica do extinto Museu Municipal do Porto - Origens, Percursos e Estudos

Sónia Couto

251 Valpaços - uma nova carta arqueológica

Pedro Pereira / Maria de Fátima Casares Machado

263 Arqueologia na Cidade de Peniche

Adriano Constantino / Luís Rendeiro

273 Arqueologia Urbana: a cidade de Lagos como caso de Estudo Cátia Neto

285 Estratégias de promoção do património cultural subaquático nos Açores. O caso da ilha do Faial

José Luís Neto / José Bettencourt / Luís Borges / Pedro Parreira

297 Carta Arqueológica da Cidade Velha: Uma primeira abordagem

Jaylson Monteiro / Nireide Tavares / Sara da Veiga / Claudino Ramos / Edson Brito /

Carlos Carvalho / Francisco Moreira / Adalberto Tavares

311 Antropologia Virtual: novas metodologias para a análise morfológica e funcional Ricardo Miguel Godinho / Célia Gonçalves

\section{Didáctica da Arqueologia}

327 Como os projetos de Arqueologia podem contribuir para uma comunidade culturalmente mais consciente Alexandra Figueiredo / Claúdio Monteiro / Adolfo Silveira / Ricardo Lopes

337 Educação Patrimonial - Um cidadão esclarecido é um cidadão ativo! Ana Paula Almeida

351 A aproximação da Arqueologia à sala de aula: um caso de estudo no $3^{\circ}$ ciclo do Ensino Básico Luís Serrão Gil

363 Arqueologia 3.o - Pensar e comunicar a Arqueologia para um futuro sustentável Mónica Rolo

377 “Conversa de Arqueólogos" - Divulgar a Arqueologia em tempos de Pandemia Diogo Teixeira Dias

389 Escola Profissional de Arqueologia: desafios e oportunidades Susana Nunes / Dulcineia Pinto / Júlia Silva / Ana Mascarenhas

399 Os Museus de Arqueologia e os Jovens: a oferta educativa para o público adolescente Beatriz Correia Barata / Leonor Medeiros

411 O museu universitário como mediador entre a ciência e a sociedade: o exemplo da secção de arqueologia no Museu de História Natural e da Ciência da Universidade do Porto (MHNC-UP)

Rita Gaspar 
421 Museu de Lanifícios: Real Fábrica de Panos. Atividades no âmbito da Arqueologia Beatriz Correia Barata / Rita Salvado

427 Arqueologia Pública e o caso da localidade da Mata (Torres Novas) Cláudia Manso / Ana Rita Ferreira / Cristiana Ferreira / Vanessa Cardoso Antunes

431 Do sítio arqueológico ao museu: um percurso (também) didático Lídia Fernandes

447 Estão todos convidados para a Festa! E para dançar também... O projecto do Serviço Educativo do Museu Arqueológico do Carmo na $5^{\underline{a}}$ Edição da Festa da Arqueologia Rita Pires dos Santos

459 O “Clã de Carenque”, um projeto didático de arqueologia Eduardo Gonzalez Rocha

469 Mediação cultural: peixe que puxa carroça nas Ruínas Romanas de Troia Inês Vaz Pinto / Ana Patrícia Magalhães / Patrícia Brum / Filipa Santos

481 Didática Arqueológica, experiências do Projeto Mértola Vila Museu Maria de Fátima Palma / Clara Rodrigues / Susana Gómez / Lígia Rafael

\section{Arte Rupestre}

497 Os inventários de arte rupestre em Portugal Mila Simões de Abreu

513 O projeto FIRST-ART - conservação, documentação e gestão das primeiras manifestações de arte rupestre no Sudoeste da Península Ibérica: as grutas do Escoural e Maltravieso Sara Garcês / Hipólito Collado / José Julio García Arranz / Luiz Oosterbeek / António Carlos Silva / Pierluigi Rosina / Hugo Gomes / Anabela Borralheiro Pereira / George Nash / Esmeralda Gomes / Nelson Almeida / Carlos Carpetudo

523 Trabalhos de documentação de arte paleolítica realizados no âmbito do projeto PalæoCôa André Tomás Santos / António Fernando Barbosa / Luís Luís / Marcelo Silvestre / Thierry Aubry

537 Imagens fantasmagóricas, silhuetas elusivas: as figuras humanas na arte do Paleolítico Superior da região do Côa Mário Reis

$55^{1}$ Os motivos zoomórficos representados nas placas de tear de Vila Nova de São Pedro (Azambuja, Portugal) Andrea Martins / César Neves / José M. Arnaud / Mariana Diniz

571 Arte Rupestre do Monte de Góios (Lanhelas, Caminha). Síntese dos resultados dos trabalhos efectuados em 2007-2009 Mário Varela Gomes

599 Gravuras rupestres de barquiformes no Monte de S. Romão, Guimarães, Noroeste de Portugal Daniela Cardoso

613 Círculos segmentados gravados na Bacia do Rio Lima (Noroeste de Portugal): contributos para o seu estudo Diogo Marinho / Ana M.S. Bettencourt / Hugo Aluai Sampaio

631 Equídeos gravados no curso inferior do Rio Mouro, Monção (NW Portugal). Análise preliminar Coutinho, L.M. / Bettencourt, A.M.S / Sampaio, Hugo A.S

645 Paletas na Arte Rupestre do Noroeste de Portugal. Inventário preliminar Bruna Sousa Afonso / Ana M. S. Bettencourt / Hugo A. Sampaio 


\section{Pré-História}

661 O projeto Miño/Minho: balanço de quatro anos de trabalhos arqueológicos Sérgio Monteiro-Rodrigues / João Pedro Cunha-Ribeiro / Eduardo Méndez-Quintas / Carlos Ferreira / Pedro Xavier / José Meireles / Alberto Gomes / Manuel Santonja / Alfredo Pérez-González

677 A ocupação paleolítica da margem esquerda do Baixo Minho: a indústria lítica do sítio de Pedreiras 2 (Monção, Portugal) e a sua integração no contexto regional Carlos Ferreira / João Pedro Cunha-Ribeiro / Sérgio Monteiro-Rodrigues / Eduardo Méndez-Quintas / Pedro Xavier / José Meireles / Alberto Gomes / Manuel Santonja / Alfredo Pérez-González

693 O sítio acheulense do Plistocénico médio da Gruta da Aroeira Joan Daura / Montserrat Sanz / Filipa Rodrigues / Pedro Souto / João Zilhão

703 As sociedades neandertais no Barlavento algarvio: modelos preditivos com recurso aos SIG

Daniela Maio

715 A utilização de quartzo durante o Paleolítico Superior no território dos vales dos rios Vouga e Côa

Cristina Gameiro / Thierry Aubry / Bárbara Costa / Sérgio Gomes / Luís Luís / Carmen Manzano / André Tomás Santos

733 Uma perspetiva diacrónica da ocupação do concheiro do Cabeço da Amoreira (Muge, Portugal) a partir da tecnologia lítica Joana Belmiro / João Cascalheira / Célia Gonçalves

745 Novos dados sobre a Pré-história Antiga no concelho de Palmela. A intervenção arqueológica no sítio do Poceirão I

Michelle Teixeira Santos

757 Problemas em torno de Datas Absolutas Pré-Históricas no Norte do Alentejo Jorge de Oliveira

771 Povoamento pré-histórico nas áreas montanhosas do NO de Portugal: o Abrigo 1 de Vale de Cerdeira Pedro Xavier / José Meireles / Carlos Alves

783 Apreciação do povoamento do Neolítico Inicial na Baixa Bacia do Douro. A Lavra I (Serra da Aboboreira) como caso de estudo Maria de Jesus Sanches

797 O Processo de Neolitização na Plataforma do Mondego: os dados do Sector C do Outeiro dos Castelos de Beijós (Carregal do Sal)

João Carlos de Senna-Martinez / José Manuel Quintã Ventura / Andreia Carvalho / Cíntia Maurício

823 Novos trabalhos na Lapa da Bugalheira (Almonda, Torres Novas) Filipa Rodrigues / Pedro Souto / Artur Ferreira / Alexandre Varanda / Luís Gomes / Helena Gomes / João Zilhão

837 A pedra polida e afeiçoada do sítio do Neolítico médio da Moita do Ourives (Benavente, Portugal)

César Neves

857 Casal do Outeiro (Encarnação, Mafra): novos contributos para o conhecimento do povoamento do Neolítico final na Península de Lisboa.

Cátia Delicado / Carlos Maneira e Costa / Marta Miranda / Ana Catarina Sousa

873 Stresse infantil, morbilidade e mortalidade no sítio arqueológico do Neolítico Final/ Calcolítico ( $4^{\circ}$ e $3^{\circ}$ milénio a.C.) do Monte do Carrascal 2 (Ferreira do Alentejo, Beja) Liliana Matias de Carvalho / Sofia N. Wasterlain 
885 Come together: O Conjunto Megalítico das Motas (Monção, Viana do Castelo) e as expressões Campaniformes do Alto Minho Ana Catarina Basílio / Rui Ramos

899 Trabalhos arqueológicos no sítio Calcolítico da Pedreira do Poio Carla Magalhães / João Muralha / Mário Reis / António Batarda Fernandes

913 O sítio arqueológico de Castanheiro do Vento. Da arquitectura do sítio à arquitectura de um território João Muralha Cardoso

925 Estudo zooarqueológico das faunas do Calcolítico final de Vila Nova de São Pedro (Azambuja, Portugal): Campanhas de 2017 e 2018 Cleia Detry / Ana Catarina Francisco / Mariana Diniz / Andrea Martins / César Neves / José Morais Arnaud

943 As faunas depositadas no Museu Arqueológico do Carmo provenientes de Vila Nova de São Pedro (Azambuja): as campanhas de 1937 a 1967 Ana Catarina Francisco / Cleia Detry / César Neves / Andrea Martins / Mariana Diniz / José Morais Arnaud

959 Análise funcional de material lítico em sílex do castro de Vila Nova de S. Pedro (Azambuja, Portugal): uma primeira abordagem Rafael Lima

971 O recinto da Folha do Ouro 1 (Serpa) no contexto dos recintos de fossos calcolíticos alentejanos

António Carlos Valera / Tiago do Pereiro / Pedro Valério / António M. Monge Soares

\section{Proto-História}

987 Produção de sal marinho na Idade do Bronze do noroeste Português. Alguns dados para uma reflexão

Ana M. S. Bettencourt / Sara Luz / Nuno Oliveira / Pedro P. Simões / Maria Isabel C. Alves / Emílio Abad-Vidal

1001 A estátua-menir do Pedrão ou de São Bartolomeu do Mar (Esposende, noroeste de Portugal) no contexto arqueológico da fachada costeira de entre os rios Neiva e Cávado Ana M. S. Bettencourt / Manuel Santos-Estévez / Pedro Pimenta Simões / Luís Gonçalves

1015 O Castro do Muro (Vandoma/Baltar, Paredes) - notas para uma biografia de ocupação da Idade do Bronze à Idade Média

Maria Antónia D. Silva / Ana M. S. Bettencourt / António Manuel S. P. Silva / Natália Félix

1031 Do Bronze Final à Idade Média - continuidades e hiatos na ocupação de Povoados em Oliveira de Azeméis João Tiago Tavares / Adriaan de Man

1041 As faunas do final da Idade do Bronze no Sul de Portugal: leituras desde o Outeiro do Circo (Beja)

Nelson J. Almeida / Íris Dias / Cleia Detry / Eduardo Porfírio / Miguel Serra

1055 A Espada do Monte das Oliveiras (Serpa) - uma arma do Bronze Pleno do Sudoeste Rui M. G. Monge Soares / Pedro Valério / Mariana Nabais / António M. Monge Soares

1065 São Julião da Branca (Albergaria-a-Velha) - Investigação e valorização de um povoado do Bronze Final

António Manuel S. P. Silva / Paulo A. P. Lemos / Sara Almeida e Silva / Edite Martins de Sá

1083 Do castro de S. João ao Mosteiro de Santa Clara: notícia de uma intervenção arqueológica, em Vila do Conde Rui Pinheiro 
1095 O castro de Ovil (Espinho), um quarto de século de investigação - resultados e questões em aberto

Jorge Fernando Salvador / António Manuel S. P. Silva

1111 O Castro de Salreu (Estarreja), um povoado proto-histórico no litoral do Entre Douro e Vouga

Sara Almeida e Silva / António Manuel S. P. Silva / Paulo A. P. Lemos / Edite Martins de Sá

1127 Castro de Nossa Senhora das Necessidades (Sernancelhe): uma primeira análise artefactual Telma Susana O. Ribeiro

${ }_{1141}$ A cividade de Bagunte. O estado atual da investigação Pedro Brochado de Almeida

1153 Zoomorfos na cerâmica da Idade do Ferro no NW Peninsular: inventário, cronologias e significado Nuno Oliveira / Cristina Seoane

1163 Vasos gregos em Portugal: diferentes maneiras de contar a história do intercâmbio cultural na Idade do Ferro

Daniela Ferreira

1175 Os exotica da necrópole da Idade do Ferro do Olival do Senhor dos Mártires (Alcácer do Sal) no seu contexto regional

Francisco B. Gomes

\section{Antiguidade Clássica e Tardia}

1191 O uso de madeira como combustível no sítio da Quinta de Crestelos (Baixo Sabor): da Idade do Ferro à Romanização Filipe Vaz / João Tereso / Sérgio Simões Pereira / José Sastre / Javier Larrazabal Galarza / Susana Cosme / José António Pereira / Israel Espi

1207 Cultivos de Época Romana no Baixo Sabor: continuidade em tempos de mudança? João Pedro Tereso / Sérgio Simões Pereira / Filipe Santos / Luís Seabra / Filipe Vaz

1221 A casa romana na Hispânia: aplicação dos modelos itálicos nas províncias ibéricas Fernanda Magalhães / Diego Machado / Manuela Martins

1235 As pinturas murais romanas da Rua General Sousa Machado, n. ${ }^{5}$ 1, Chaves José Carvalho

1243 Trás do Castelo (Vale de Mir, Pegarinhos, Alijó) - Uma exploração agrícola romana do Douro

Tony Silvino / Pedro Pereira

1255 A sequência de ocupação no quadrante sudeste de Bracara Augusta: as transformações de uma unidade doméstica Lara Fernandes / Manuela Martins

1263 Os Mosaicos com decoração geométrica e geométrico-vegetalista dos sítios arqueológicos da área do Conuentus Bracaraugustanus. Novas abordagens quanto à conservação, restauro, decoração e datação Maria de Fátima Abraços / Licínia Wrench

1277 “Casa Romana” do Castro de São Domingos (Cristelos, Lousada): Escavação, Estudo e Musealização Paulo André de P. Lemos

1291 A arqueobotânica no Castro de Guifões (Matosinhos, Noroeste de Portugal): O primeiro estudo carpológico

Luís Seabra / Andreia Arezes / Catarina Magalhães / José Varela / João Pedro Tereso 
1305 Um Horreum Augustano na Foz do Douro (Monte do Castelo de Gaia, Vila Nova de Gaia) Rui Ramos

1311 Ponderais romanos na Lusitânia: padrões, formas, materiais e contextos de utilização Diego Barrios Rodríguez

1323 Um almofariz centro-itálico na foz do Mondego

Marco Penajoia

1335 Estruturas romanas de Carnide - Lisboa Luísa Batalha / Mário Monteiro / Guilherme Cardoso

1347 O contexto funerário do sector da "necrópole NO" da Rua das Portas de S. Antão (Lisboa): o espaço, os artefactos, os indivíduos e a sua interconectividade na interpretação do passado Sílvia Loja, José Carlos Quaresma, Nelson Cabaço, Marina Lourenço, Sílvia Casimiro, Rodrigo Banha da Silva, Francisca Alves-Cardoso

${ }_{1361}$ Povoamento em época Romana na Amadora - resultados de um projeto pluridisciplinar Gisela Encarnação / Vanessa Dias

1371 A Arquitectura Residencial em Mirobriga (Santiago do Cacém): contributo a partir de um estudo de caso Filipe Sousa / Catarina Felício

${ }_{1385}$ O fim do ciclo. Saneamento e gestão de resíduos nos edifícios termais de Mirobriga (Santiago do Cacém)

Catarina Felício / Filipe Sousa

1399 Balsa, Topografia e Urbanismo de uma Cidade Portuária Vítor Silva Dias / João Pedro Bernardes / Celso Candeias / Cristina Tété Garcia

1413 No Largo das Mouras Velhas em Faro (2017): novas evidências da necrópole norte de Ossonoba e da sua ocupação medieval Ricardo Costeira da Silva / Paulo Botelho / Fernando Santos / Liliana Nunes

1429 Instrumentos de pesca recuperados numa fábrica de salga em Ossonoba (Faro) Inês Rasteiro / Ricardo Costeira da Silva / Paulo Botelho

1439 A Necrópole Romana do Eirô, Duas Igrejas (Penafiel): intervenção arqueológica de 2016 Laura Sousa / Teresa Soeiro

1457 Ritual, descarte ou afetividade? A presença de Canis lupus familiaris na Necrópole Noroeste de Olisipo (Lisboa)

Beatriz Calapez Santos / Sofia Simões Pereira / Rodrigo Banha da Silva / Sílvia Casimiro / Cleia Detry / Francisca Alves Cardoso

1467 Dinâmicas económicas em Bracara na Antiguidade Tardia Diego Machado / Manuela Martins / Fernanda Magalhães / Natália Botica

1479 Cerâmicas e Vidros da Antiguidade Tardia do Edifício sob a Igreja do Bom Jesus (Vila Nova de Gaia) Joaquim Filipe Ramos

1493 Novos contributos para a topografia histórica de Mértola no período romano e na Antiguidade Tardia Virgílio Lopes

\section{8. Época Medieval}

1511 Cerâmicas islâmicas no Garb setentrional "português": algumas evidências e incógnitas Constança dos Santos / Helena Catarino / Susana Gómez / Maria José Gonçalves / Isabel Inácio / Gonçalo Lopes / Jacinta Bugalhão / Sandra Cavaco / Jaquelina Covaneiro / Isabel Cristina Fernandes / Ana Sofia Gomes 
1525 Contributo para o conhecimento da cosmética islâmica, em Silves, durante a Idade Média Rosa Varela Gomes

1537 Yábura e o seu território - uma análise histórico-arqueológica de Évora entre os séculos VIII-XII José Rui Santos

1547 A encosta sul do Castelo de Palmela - resultados preliminares da escavação arqueológica Luís Filipe Pereira / Michelle Teixeira Santos

1559 A igreja de São Lourenço (Mouraria, Lisboa): um conjunto de silos e de cerâmica medieval islâmica

Andreia Filipa Moreira Rodrigues

1571 O registo material de movimentações populacionais no Médio Tejo, durante os séculos XII-XIII. Dois casos de "sunken featured buildings", nos concelhos de Cartaxo e Torres Novas Marco Liberato / Helena Santos / Nuno Santos

1585 O nordeste transmontano nos alvores da Idade média. Notas para reflexão Ana Maria da Costa Oliveira

1601 Sepulturas escavadas na rocha do Norte de Portugal e do Vale do Douro: primeiros resultados do Projecto SER-NPVD

Mário Jorge Barroca / César Guedes / Andreia Arezes / Ana Maria Oliveira

1619 "Portucalem Castrum Novum" entre o Mediterrâneo e o Atlântico: o estudo dos materiais cerâmicos alto-medievais do arqueossítio da rua de D. Hugo, nํ. 5 (Porto) João Luís Veloso

1627 A Alta Idade Média na fronteira de Lafões: notas preliminares sobre a Arqueologia no Concelho de Vouzela

Manuel Luís Real / Catarina Tente

1641 Um conjunto cerâmico medieval fora de portas: um breve testemunho aveirense Susana Temudo

${ }_{1651}$ Os Lóios do Porto: uma perspetiva integrada no panorama funerário da Baixa Idade Média à Época Moderna em meios urbanos em Portugal

Ana Lema Seabra

1659 O Caminho Português Interior de Santiago como eixo viário na Idade Média Pedro Azevedo

1665 Morfologia Urbana: Um exercício em torno do Castelo de Ourém André Donas-Botto / Jaqueline Pereira

1677 Intervenção arqueológica na Rua Marquês de Pombal/Largo do Espírito Santo (Bucelas, Loures)

Florbela Estêvão / Nathalie Antunes-Ferreira / Dário Ramos Neves / Inês Lisboa

1691 O Cemitério Medieval do Poço do Borratém e a espacialidade funerária na cidade de Lisboa Inês Belém / Vanessa Filipe / Vasco Noronha Vieira / Sónia Ferro / Rodrigo Banha da Silva

1705 Um Espaço Funerário Conventual do séc. XV em Lisboa: o caso do Convento de São Domingos da Cidade Sérgio Pedroso / Sílvia Casimiro / Rodrigo Banha da Silva / Francisca Alves Cardoso

\section{9. Época Moderna e Contemporânea}

1721 Arqueologia Moderna em Portugal: algumas reflexões críticas em torno da quantificação de conjuntos cerâmicos e suas inferências históricas e antropológicas Rodrigo Banha da Silva / André Bargão / Sara da Cruz Ferreira

1733 Faianças de dois contextos entre os finais do século XVI e XVIII do Palácio dos Condes de Penafiel, Lisboa

Martim Lopes / Tomás Mesquita 
1747 Um perfil de consumo do século XVIII na foz do Tejo: O caso do Mercado da Ribeira, Lisboa Sara da Cruz Ferreira / Rodrigo Banha da Silva / André Bargão

1761 Os Cachimbos dos Séculos XVII e XVIII do Palácio Mesquitela e Convento dos Inglesinhos (Lisboa)

Inês Simão / Marina Pinto / João Pimenta / Sara da Cruz Ferreira / André Bargão / Rodrigo Banha da Silva

1775 "Tomar os fumos da erua que chamão em Portugal erua sancta». Estudo de Cachimbos provenientes da Rua do Terreiro do Trigo, Lisboa

Miguel Martins de Sousa / José Pedro Henriques / Vanessa Galiza Filipe

1787 Cachimbos de Barro Caulínitico da Sé da Cidade Velha (República de Cabo Verde)

Rodrigo Banha da Silva / João Pimenta / Clementino Amaro

1801 Algumas considerações sobre espólio não cerâmico recuperado no Largo de Jesus (Lisboa) Carlos Boavida

1815 Adereços de vidro, dos séculos XVI-XVIII, procedentes do antigo Convento de Santana de Lisboa (anéis, braceletes e contas)

Joana Gonçalves / Rosa Varela Gomes / Mário Varela Gomes

1837 Da ostentação, luxo e poder à simplicidade do uso quotidiano: arqueologia e simbologia de joias e adornos da Idade Moderna Portuguesa Jéssica Iglésias

1849 Os amuletos em Portugal - dos objetos às superstições: o coral vermelho Alexandra Vieira

1865 Cerâmicas de Vila Franca de Xira nos séculos XV e XVI Eva Pires

1879 «Não passa por teu o que me pertence». Marcas de individualização associadas a faianças do Convento de Nossa Senhora de Aracoeli, Alcácer do Sal Catarina Parreira / Íris Fragoso / Miguel Martins de Sousa

1891 Cerâmica de Leiria: alguns focos de produção

Jaqueline Pereira / André Donas-Botto

1901 Os Fornos na Rua da Biquinha, em Óbidos Hugo Silva / Filipe Oliveira

1909 A casa de Pêro Fernandes, contador dos contos de D. Manuel I: o sítio arqueológico da Silha do Alferes, Seixal (século XVI) Mariana Nunes Ferreira

1921 O Alto da Vigia (Sintra) e a vigilância e defesa da costa Alexandre Gonçalves / Sandra Santos

1937 O contexto da torre sineira da Igreja de Santa Maria de Loures Paulo Calaveira / Martim Lopes

1949 A Necrópole do Hospital Militar do Castelo de São Jorge e as práticas funerárias na Lisboa de Época Moderna Susana Henriques / Liliana Matias de Carvalho / Ana Amarante / Sofia N. Wasterlain

1963 SAND - Sarilhos Grandes Entre dois Mundos: o adro da Igreja e a Paleobiologia dos ossos humanos recuperados

Paula Alves Pereira / Roger Lee Jesus / Bruno M. Magalhães

1975 Expansão urbana da vila de Cascais no século XVII e XVIII: a intervenção arqueológica na Rua da Vitória no 15 a 17

Tiago Pereira / Vanessa Filipe

1987 Novos dados para o conhecimento do Urbanismo de Faro em época Moderna Ana Rosa 
1995 Um exemplo de Arqueologia Urbana em Alcoutim: o Antigo Edifício dos CTT Marco Fernandes / Marta Dias / Alexandra Gradim / Virgílio Lopes / Susana Gómez Martínez

2007 Palácio dos Ferrazes (Rua das Flores/Rua da Vitória, Porto): a cocheira de Domingos Oliveira Maia

Francisco Raimundo

2021 As muitas vidas de um edifício urbano: História, Arqueologia e Antropologia no antigo Recreatório Paroquial de Penafiel Helena Bernardo / Jorge Sampaio / Marta Borges

2035 O convento de Nossa Senhora da Esperança de Ponta Delgada: o contributo da arqueologia para o conhecimento de um monumento identitário João Gonçalves Araújo / N’Zinga Oliveira

2047 Arqueologia na ilha do Corvo... em busca da capela de Nossa Senhora do Rosário Tânia Manuel Casimiro / José Luís Neto / Luís Borges / Pedro Parreira

2059 Perdidos à vista da Costa. Trabalhos arqueológicos subaquáticos na Barra do Tejo Jorge Freire / José Bettencourt / Augusto Salgado

2071 Arqueologia marítima em Cabo Verde: enquadramento e primeiros resultados do projecto CONCHA

José Bettencourt / Adilson Dias / Carlos Lima / Christelle Chouzenoux / Cristóvão Fonseca / Dúnia Pereira / Gonçalo Lopes / Inês Coelho / Jaylson Monteiro / José Lima / Maria Eugénia Alves / Patrícia Carvalho / Tiago Silva

2085 Trabalhos arqueológicos na Cidade Velha (Ribeira Grande de Santiago, Cabo Verde): reflexões sobre um projecto de investigação e divulgação patrimonial André Teixeira / Jaylson Monteiro / Mariana Mateus / Nireide Tavares / Cristovão Fonseca / Gonçalo C. Lopes / Joana Bento Torres / Dúnia Pereira / André Bargão / Aurélie Mayer / Bruno Zélie / Carlos Lima / Christelle Chouzenoux / Inês Henriques / Inês Pinto Coelho / José Lima / Patrícia Carvalho / Tiago Silva

2103 A antiga fortificação de Quelba / Khor Kalba (E.A.U.). Resultados de quatro campanhas de escavações, problemáticas e perspectivas futuras Rui Carita / Rosa Varela Gomes / Mário Varela Gomes / Kamyar Kamyad

2123 Colónias para homens novos: arqueologia da colonização agrária fascista no noroeste ibérico Xurxo Ayán Vila / José Mạ . Señorán Martín 


\title{
PERDIDOS À VISTA DA COSTA. TRABALHOS ARQUEOLÓGICOS SUBAQUÁTICOS NA BARRA DO TEJO
}

\author{
Jorge Freire ${ }^{\mathrm{T}}$, José Bettencourt ${ }^{2}$, Augusto Salgado ${ }^{3}$
}

\begin{abstract}
RESUMO
Desde tempos imemoriais que todos os navios que entram ou saem de Lisboa, capital de um vasto Império Marítimo desde o século XV, têm que passar por um dos dois canais estreitos na entrada do Tejo. Esses canais encontram-se limitados não apenas pelas margens, como também por duas línguas de areia, denominadas “Cachopos”. Pela sua geografia, esta área está bem protegida dos ventos do norte ou leste, mas completamente aberta a tempestades do sul. Principalmente durante essas tempestades, foram vários os navios que naufragaram na costa norte, ou contra ambos os cachopos. Desde a década de 1960 que vários naufrágios modernos e contemporâneos foram ali descobertos. Esta comunicação pretende apresentar os trabalhos que têm estado a decorrer na zona desde 2015, no âmbito da Carta Arqueológica Subaquática de Cascais.
\end{abstract}

Palavras-chave: Arqueologia Marítima, Arqueologia Subaquática, Atlântico, Tejo.

\begin{abstract}
All ships entering or leaving Lisbon, the capital of a vast Maritime Empire since the $15^{\text {th }}$ century, have to pass through one of the two narrow canals at the entrance to the Tagus. These channels are limited by the coast but also by two sand banks, called "Cachopos". By its geography, this area is well protected from the north or east winds, but entirely open to southern storms. Especially during these storms, several ships sank on the north coast, or against both sand banks. Since the 196os, several early modern and contemporary shipwrecks have been discovered in this area. This communication intends to present the work taking place since 2015, within the framework of the Cascais Underwater Archaeological Chart.
\end{abstract}

Keywords: Maritime Archaeology, Underwater Archaeology, Atlantic, Tagus river.

\section{INTRODUÇÃO}

No entender de Cascais, os valores culturais do município são testemunhos com valor de civilização ou de cultura, portadores de interesse relevante, devendo como tal ser objeto de especial proteção e valorização. O modelo consignado no Plano Diretor Municipal define como património arqueológico todos os vestígios, bens e outros indícios da evolução do Homem, designadamente sítios, depósitos estratificados, estruturas, construções, agrupamentos arquitetónicos, sítios valorizados, bens móveis e monumentos de outra natureza, bem como o respe- tivo contexto, quer estejam localizados em meio rural ou urbano, no solo, subsolo ou em meio submerso, no mar territorial ou na plataforma continental. Este modelo de gestão e protecção explica a aposta municipal na carta arqueológica subaquática de Cascais (PROCASC). Em curso desde 2009, este projecto adoptou uma abordagem holística ao património cultural subaquático, visto enquanto elemento de uma Paisagem Cultural Marítima em constante construção (Freire, 2014). Aqui, a arqueologia subaquática não se limita ao estudo da história através dos artefactos que o tempo nos legou. Reflete também a ligação do Homem ao meio ambiente. A concepção

\footnotetext{
1. Câmara Municipal de Cascais; jorge.freire@cm-cascais.pt

2. CHAM - Centro de Humanidades e FCSH, Universidade Nova de Lisboa; jbettencourt.cham@gmail.com

3. Centro de História da Faculdade de Letras da Univ. Lisboa e CINAV; alves.salgado@marinha.pt
} 
de Paisagem Cultural Marítima - "the whole network of sailing routes, with ports, havens and harbours along the coast, and its related constructions and other remains of human activity, underwater as well terrestrial" (Westerdahl 2011: 212), aproxima-nos do conceito metafísica de Bruno Latour (Actor Network Theory), que procura compreender a paisagem através de uma rede de relações sociais e económicas que se estabelece entre o humano e o não humano (Latour, 2005). Os bens arqueológicos deixam de ser apenas artefactos, cuja significação é atribuída pelo homem, e passam a ser agência, ou seja, participam das ações nas situações quotidianas e provocam transformações. Esta participação remete-nos para um último aspeto concetual, que foi sinteticamente resumido por Lofgren (1981) - a nossa perceção enquanto atores da paisagem atual e histórica: "the mapping and imprinting of the functional aspects of the surroundings in the human mind. Man in landscape, landscape in man" (apud Westerdahl, 1992).

Os despojos perdidos nas águas de Cascais são assim um reflexo das dificuldades que os navios encontraram neste mar, que se traduziu em várias tragédias humanas. Mas são também novos focos de vida, ao transformarem-se em habitats únicos para o desenvolvimento e fixação da biodiversidade marinha, que se revestem de interesse económico e cultural para os vários utentes do mar e para a comunidade em geral. Estes sítios constituem, também, uma simbiose única de História, estruturas sociais e sistemas ecológicos. Eles ilustram a utilização milenar do meio aquático, considerando as características e as vantagens oferecidas pelo ambiente natural, do mesmo modo que relacionam o estabelecimento humano na costa ao longo dos tempos, através da existência de zonas de naufrágio e áreas de navegação. O seu conhecimento contribui para a gestão sustentada do mar e da costa, preservando ou aumentando a sua diversidade biológica, sendo por isso de estudo necessariamente interdisciplinar.

O PROCASC procurou consequentemente responder aos maiores desafios da moderna arqueologia subaquática, em transformação devido à crescente aposta na multidisciplinaridade, com novas necessidades logísticas e dos meios técnicos. O projeto da Câmara Municipal de Cascais tem sido realizado em rede, em colaboração com a Direção Geral do Património Cultural (DGPC), o Centro de Investigação Naval da Escola Naval (CINAV), o CHAM - Centro de Humanidades, da Faculdade de Ciências Sociais e Humanas da Universidade Nova de Lisboa, e a empresa de arqueologia Archaeofactory. O PROCASC tem igualmente desenvolvido novas parcerias, potenciando sinergias que resultaram na aplicação de métodos de trabalho inovadores, por equipas verdadeiramente transdisciplinares. Os trabalhos têm ultrapassado as ciências sociais e humanas, através da aceitação do contributo de outras áreas, menos suspeitas, como a biologia e a robótica oceanográfica. Neste âmbito, o apoio do Laboratório de Robótica e Sistemas de Engenharia do Instituto Superior Técnico (LaRSYS), da Estrutura de Missão para a Extensão da Plataforma Continental (EMEPC) e da Agência Portuguesa do Ambiente (APA) foram essenciais.

O projeto desenvolve igualmente um programa educacional de património arqueológico de uma forma viva, transformando momentos multidisciplinares de laboratório em ações de sensibilização e de educação, promovendo a fruição direta aos elementos de várias proveniências académicas e sociais, procurando uma transmissão recíproca do valor identitário e sentimental do património. A formação, o treino dos arqueólogos e a prática do mergulho têm, deste modo, vindo a adaptar-se às novas tecnologias, cabendo na experiência deste projecto através da realização de estágios académicos de alunos de várias universidades portuguesas. Mais ainda, as actividades desenvolvidas têm permitido a aproximação entre aquilo que é público - entendido como atribuições e deveres dos organismos municipais e de Estado - e difuso - baseado no conhecimento popular e na pertença de uma comunidade costeira ou ribeirinha. Esta abordagem tem incluído, além das formas usuais de divulgação científica e das apresentações anuais à comunidade local, a difusão mais lata, alcançada através de disseminações de maior escala, como são o caso da revista National Geographic Society Portugal ou as actividades com a Rede de Escolas Associadas da Comissão Nacional da UNESCO Portugal. Por tudo isto, o Projeto Municipal de Arqueologia Subaquática de Cascais foi considerado um projeto "Boas Práticas" pela UNESCO, em maio de 2017, no âmbito da Convenção 2001 para a Proteção do Património Cultural Subaquático.

Com um âmbito de acção que abarca a costa do concelho de Cascais, entre o Cabo da Roca e São Julião da Barra, este artigo apresenta dos principais resultados obtidos entre 2015 e 2019, com especial incidência sobre o Bugio, espaço com um lugar especial na paisagem marítima do litoral português. 


\section{DESTROÇOS CONTEMPORÂNEOS NO BUGIO}

A quasi maritimidade do espaço geograficamente delimitada por dois promontórios, Cabo da Roca e Cabo Espichel, é interrompida a meio pela existência da embocadura do estuário do rio Tejo. Nesta, as trocas culturais são de longa duração e foram capturadas por uma história polvilhada de dinâmicas, continuidades e ruturas (Freire, 2014). Esta área é um paradoxo natural em si mesmo. Não é rio, mas também não é oceano. É uma zona de transporte marítimo em que o estuário condiciona, transforma e modifica o presente numa história de longa duração, marcada pela frequente perda de navios, contra a costa e nos areais dos Cachopos.

No Cachopo Sul, areal do Bugio, a uma profundidade que oscila entre os 7 e os 15 metros, a vida marinha refugia-se por entre os restos metálicos de dois naufrágios esquecidos. A memória do local, essa, perdura pelas visitas frequentes e atrevidas dos pescadores e dos praticantes de caça submarina (Figura 1).

Foi essa ligação à vida marinha que levou à redescoberta destes destroços em 2015, no âmbito da última campanha da M@RBIS, da Estrutura de Missão para a Extensão da Plataforma Continental (EMEPC), naquela que foi a primeira incursão da arqueologia na área do Bugio. Felizmente, nesta campanha, os biólogos eram acompanhados por dois arqueólogos da Câmara Municipal de Cascais, que imediatamente divulgam à comunidade a história desse "pequeno herói” (Rosa, 2015).

Esses vestígios iam ficando mais ou menos à vista, conforme as dinâmicas sedimentares da barra do estuário do Tejo (Figura 2). O Navio de Salvamento Patrão Lopes, totalmente desconhecido da maioria da comunidade científica, ou de localização incerta para os que conheciam a sua história, haveria de ressurgir num encontro feliz, mas inopinado, entre uns e outros.

A história do Patrão Lopes termina abruptamente, após 20 anos de um percurso exemplar ao serviço da Armada portuguesa. No dia 29 de Fevereiro de 1936, durante um violento temporal, tentava entrar a barra de Lisboa dando reboque, de braço dado, a um grande batelão de nome Franz que, à deriva, se tornara um perigo para a navegação. Subitamente, o Patrão Lopes é arrastado pelo batelão e sai do canal de navegação. Os dois encalham no areal do Bugio. O Franz afunda-se primeiro. Os seus mastros acabam por perfurar o casco do velho navio de salvamento, que acaba também por se perder (Figura 2).

Apesar de ter navegado sob bandeira portuguesa desde Abril de 1916, o navio foi construído em 188o, em Rostock, no Nordeste da Alemanha, pela Rostocker Act. Ges. Tinha 49 metros de comprimento, deslocava 467 toneladas brutas e tinha uma tripulação de 63 elementos. Era, a 23 de Fevereiro de 1916, o mais pequeno dos 72 navios das potências centrais (Alemanha e Império Austro-húngaro) que se encontravam refugiados em portos nacionais desde o início do confronto e que, nesse dia, foram requisitados e ocupados por elementos da Marinha portuguesa.

O Newa, à semelhança do conhecido Gil Eannes, também foi integrado na Armada, inicialmente com o nome Patrão Joaquim Lopes e, logo depois, apenas com o nome Patrão Lopes, em singela homenagem a um herói de muitos salvamentos na barra de Lisboa. De imediato, dá início a uma intensa actividade de salvamento que vai caracterizar o seu percurso, nos próximos 20 anos, de navegação sob bandeira portuguesa (Oliveira, 1936).

A descoberta do Patrão Lopes, no âmbito da campanha M@rbis 2015, deu origem a um programa específico de estudo colaborativo. Podendo tratar-se de um navio que pertenceu à Marinha Portuguesa, rapidamente o Centro de Investigação Naval (CINAV) da Marinha efetuou um conjunto de ações para confirmar a correlação entre destroço-navio, para avaliar as ações necessárias no futuro próximo, juntamente com elementos da Câmara Municipal de Cascais.

Encontrando-se os despojos em excelente estado de conservação, possivelmente devido aos longos anos que esteve quase todo tapado pela areia, são várias as possibilidades futuras para a preservação e dinamização deste último e único sobrevivente da " $c a$ sus belli" que levou Portugal a entrar, formalmente, na Grande Guerra.

Ainda antes do final desse Verão, e durante um levantamento geofísico com multifeixe do navio de salvamento Patrão Lopes, o mestre da embarcação da Administração do Porto de Lisboa (APL) que prestava assistência aos trabalhos indicou a localização de um novo destroço, que teria permanecido esquecido nas páginas da Ilustração Portuguesa e nos arquivos de Marinha e das Minas de São Domingos, não fosse esta importantíssima ligação entre a "academia" e os utilizadores do mar.

De acordo com as fontes, terá sido o temporal que se abateu na costa Ocidental de Portugal continen- 
tal nos dias 8 e 9 de Fevereiro de 1923 a provocar o afundamento do rebocador Rhona junto ao Bugio. O navio vinha a Lisboa para proceder a reparações, trazendo 9 pessoas a bordo.

Este pequeno rebocador, de 141 toneladas de Deslocamento Bruto e cerca de 30 metros de comprimento, pertencia à Mason \& Barry, empresa proprietária das Minas de S. Domingos (Mértola). Era habitualmente utilizado para rebocar as barcaças com minério entre o Pomarão e Vila Real de Santo António através do Guadiana, onde aquele era embarcado em navios maiores com destino a Inglaterra. O navio tinha sido construído em Inglaterra em 1897, precisamente para a Mason \& Barry. A viagem que tinha começado no Algarve às 17:0o do dia 6 , começou a complicar-se cerca de 24 horas depois, com o vento de sudoeste a aumentar até ao navio passar o Espichel. Foi já com o enfiamento da barra de Lisboa à vista que um conjunto de grandes ondas apanhou o rebocador, rebentado nas superestruturas do navio, provocando diversas avarias e entrada de água. Uma das ondas chegou mesmo a levar parte da ponte do pequeno rebocador, que assim ficou completamente desgovernado. Nesta altura, já perto do farol do Bugio, a tripulação conseguiu largar o ferro e começou a emitir sinais de socorro. Cerca das 22:0o horas, quando parecia aos tripulantes que tudo já estava perdido, estes juntaram-se na câmara, "dispostos a morrer ali". Os sobreviventes acabaram por subir ao que restava da ponte e ao mastro do navio, e ao nascer do dia, apenas já só lá estavam dois.

Foi nessa altura que chegou o salva-vidas de Paço d'Arcos, que a remos e, apesar do estado do mar, conseguiu aproximar-se do que restava do rebocador. $\mathrm{O}$ mestre do salva-vidas atirou-se ao mar, conseguindo colocar um cabo no mastro e, assim, salvar os dois únicos sobreviventes da tripulação do Rhon ${ }^{4}$.

Naturalmente, que em 2016 e 2017 foram realizados os mergulhos com o objectivo de tentar confirmar a identidade dos destroços (Figura 3), nomeadamente com recurso a metodologias arqueológicas forenses (resultados ainda preliminares), embora uma breve pesquisa na Ilustração Portuguesa nos tivesse dado pistas sobre a identidade do naufrágio de imediato (Figura 3).

4. Ilustração Portuguesa, №887, de 17 Fevereiro 1923, p.205, e Ilustração Portuguesa, №889, de 3 Março 1923, p.274.

\section{UM “CEMITÉRIO” DE NAVIOS DE ÉPOCA MODERNA}

Com variações que não conseguimos precisar, os sedimentos que são regularmente trazidos pelo rio Tejo e transportados por processos costeiros vão sendo depositados na sua foz, nomeadamente em duas zonas laterais da "Barra Sul" do porto de Lisboa. Estes dois locais de depósito da areia formam o Cachopo Norte (junto a São Julião da Barra) e o Cachopo Sul (envolvendo o forte de S. Lourenço da Cabeça Seca, tradicionalmente conhecido por Bugio). Estas duas zonas de areia, cujas características se têm alterado ao longo dos anos, estão directamente associadas às fortes correntes provocadas pelo caudal do Tejo e às condições de mar e vento, o que as tornam particularmente perigosas para a navegação à vela.

O Cachopo Sul, em particular, chegou a prolongar-se por quase duas milhas lateralmente à Barra Sul e, na baixa-mar, era possível caminhar desde a Trafaria até ao Bugio. Nos anos 80 do século passado, ainda havia uma parte que nunca se encontrava submersa, pois tinha inclusivamente alguma vegetação.

Não é, portanto, de estranhar, que um levantamento da bibliografia aponte para, pelo menos, 23 naufrágios ocorridos especificamente no Cachopo Sul, entre os anos de 1451 e 1936 (Silva e Cardoso, 2005) e certamente que muitos outros terão ali ocorrido anteriormente.

É nesta realidade que em Outubro de 2017 mariscadores profissionais declaram a descoberta de dois destroços, um localizado entre o Bugio e a Trafaria (designado inicialmente por Tejo B, atribuído aos restos de uma embarcação com uma carga de barricas em madeira com o envase de uma substância ainda por identificar) ${ }^{5}$. O outro, então designado por Tejo A, localizava-se sensivelmente a Sudoeste do Bugio, na zona de intervenção do PROCASC. Deste local os achadores terão retirado pelo menos dois pratos de estanho, que foram depositados no Instituto de Arqueologia e Paleociências, da Faculdade de Ciências Sociais e Humanas.

No mergulho de avaliação realizado neste contexto (Bugio 1) pela equipa do PROCASC em 28 de Outubro confirmou-se a existência de dois canhões em ferro semi-enterrados e três âncoras. Para além

5. Este local não foi caracterizado pelo ProCASC, nem será tratado neste artigo, pois encontra-se fora do âmbito espacial deste projecto. 
destes vestígios, visíveis no filme disponibilizado pelos achadores e referidos no auto de achado, dois elementos do CINAV registaram ainda nas proximidades o que aparentava ser os restos de uma estrutura em madeira, apenas visível nalgumas extremidades, mas com alguma coesão. Todos os vestígios sugeriam ser pertencentes aos restos de um navio dos inícios do século XVIII, de origem e função indeterminadas (Monteiro et al., 2018).

O PROCASC retomou os trabalhos nas áreas do projeto em julho de 2018, incluindo o espaço circundante ao Bugio, tendo realizado um novo mergulho de verificação no local do Tejo A. Apesar da visibilidade reduzida, verificou-se que o local se encontrava muito menos assoreado. Era possível visualizar um maior número de peças de artilharia em ferro e de âncoras, sobre areia e lastro em pedra (Figura 4). Em redor destas peças de maiores dimensões surgiam algumas concreções ferrosas, onde era possível identificar fragmentos de faiança portuguesa do século XVIII (Figura 5), para além de dois cadernais. Adicionalmente, aos dois conjuntos de âncoras, era agora possível vislumbrar cabos de grande bitola, habitualmente utilizados nas amarras dos navios. O interessante destas descobertas prende-se com a possível natureza do material com que eram feitos esses cabos. Apesar de não se ter efectuado nenhuma análise, estes aparentam ser, pela sua dureza, de piaçaba, fibra vegetal de origem brasileira utilizada a partir dos finais do século XVII (Hutter, 2005: 345), até ser substituído pelas amarras em corrente de ferro (Figura 4 e 5 ).

Os trabalhos no Bugio viriam a ser retomados em Setembro desse ano, tendo como objetivos determinar as potencialidades do sítio para a realização de um campus escola e para o seu levantamento com recurso a sonar de varrimento lateral pela EMEPC. Durante esta fase viriam a ser localizados vários depósitos inéditos, manifestamente distintos dos anteriores, visíveis sobretudo em quatro zonas, então designadas como Bugio 2.

Numa zona (Área C), situada $65 \mathrm{~m}$ a leste dos achados declarados em 2017, era visível um fragmento de secção central do navio, com a quilha e as balizas, constituindo por isso um indicador do eixo longitudinal do naufrágio. O bordo sul desta estrutura surgia a mais de $1 \mathrm{~m}$ de altura do nível da areia (sem estar apoiado) e as madeiras a menor profundidade mostravam evidências claras de exposições anteriores a maior escala do que a daquele momento, surgindo por exemplo parte de uma tábua de resbordo invertida e enterrada junto à quilha ou outra tábua do forro deslocada, encostada às balizas (Figura 6).

A observação preliminar desta estrutura indica tratar-se de um navio de grande porte, com paralelos próximos na nau Nossa Senhora dos Mártires, que naufragou em São Julião da Barra em 1605 quando voltava do Estado da Índia (Castro, 2005). A quilha é compósita, com alefriz, medindo $30 \mathrm{~cm}$ de altura e $23,5 \mathrm{~cm}$ de largura, na zona das escarvas, lisas verticais, que ligam diferentes troços. As balizas centrais teriam uma secção quadrangular, com cerca de 23 $\mathrm{cm}$, tendo sido observada pelo menos uma escarva na ligação caverna/ braço. As tábuas do forro exterior, com 11 a $12 \mathrm{~cm}$ de espessura, estavam fixas às balizas com pregos em ferro de secção quadrangular. $\mathrm{Na}$ calafetagem das costuras das tábuas recorreu-se à utilização de cordões de chumbo (Figura 6).

Uma segunda zona (Área B), situada a $20 \mathrm{~m}$ a norte da Área C, corresponde a uma acumulação com pelo menos cinco bocas-de-fogo em bronze, madeiras da estrutura do navio e numerosos materiais na areia pimenta, fragmentos de porcelana e cauris (Figura 7). Neste conjunto destacam-se dois pedreiros com as armas da coroa portuguesa (Figura 8) e uma acumulação de pimenta localizada sob uma provável tampa em madeira.

Uma terceira zona (Área D), situada $20 \mathrm{~m}$ a leste da Área B e a $25 \mathrm{~m}$ a nordeste da Área C, corresponde também a um depósito com três bocas-de-fogo (possivelmente do tipo colubrina ou colubrina bastarda) em bronze, elementos de madeiras e numerosas concreções, algumas com outros artefactos, nomeadamente um almofariz em pedra. Sobre os sedimentos surgem igualmente materiais, sobretudo porcelana e cauris $^{6}$ (Figura 7 e 8).

Foram mapeadas mais duas estruturas em madeira, mais afastadas. A Área F, a leste, corresponde a outro fragmento de navio, onde podem ser observadas porcelanas e outros materiais entre as balizas. $\mathrm{O}$ ângulo entre o forro exterior e as balizas sugere tratar-se uma secção extrema da embarcação. A última estrutura, de grandes dimensões, está situada cerca de

6. Após a divulgação do projecto de estudo deste contexto, fomos informados pelas "Redes Sociais" e pela própria DGPC que teriam sido recuperadas algumas peças do local, incluindo um possível almofariz de pedra, registado durante os nossos trabalhos. A retirada deste material foi considerada ilícita pelo Procurador da Comarca de Lisboa, DIAP - 4- ${ }^{-2}$ Secção de Lisboa, de 14-10-2019. 
$40 \mathrm{~m}$ a norte da Área B e $50 \mathrm{~m}$ a nordeste do Tejo A, agora designado por Bugio 1, e parece corresponder ao bordo de um navio, onde ainda não foi possível identificar características que permitam relacionar com nenhum dos contextos determinados.

Em todo o caso, os dados disponíveis à data sugerem a existência de dois naufrágios distintos numa zona com uma área de pelo menos $120 \mathrm{~m}$ no sentido oeste-leste e 50 no sul-norte. A proximidade entre as duas realidades não é surpreendente, pois há registo de pelo menos 23 naufrágios na zona dos Cachopos, entre 1451 e 1936, conforme já mencionado. Os vestígios identificados no Bugio 1 apontam para um naufrágio posterior a meados do século XVII ou inícios do século XVIII, marcado pela utilização exclusiva de artilharia em ferro, uso de lastro em pedra, presença de faiança portuguesa da época e cabos em piaçaba. Os depósitos identificados em Bugio 2 sugerem tratar-se de uma nau da Carreira da Índia, com paralelos na $N^{\underline{a}}$. Sr $r^{\underline{a}}$. dos Mártires (1606), em especial em termos de construção naval. Nos diversos núcleos, predomina a artilharia em bronze e são abundantes materiais arqueológicos relacionados com origem no Índico e Ásia, como a porcelana ou a pimenta. Uma análise das fontes, e tendo em conta as evidências materiais que este destroço apresenta, sugere podermos estar na presença dos vestígios da nau portuguesa São Francisco Xavier, perdida a 23 de Outubro de 1625 quando regressava da Índia nos baixios da Cabeça Seca (Silva e Cardoso, 2005: 63).

\section{OS AVANÇOS DE 2019}

Os trabalhos no Bugio efetuados durante a campanha de 2019 decorreram em dois períodos distintos, entre 27 de Maio e 1 de Julho e 2 de Agosto e 16 de Setembro, tendo o trabalho sido dividido em quatro fases - monitorização, mapeamento, delimitação, caracterização e avaliação dos contextos -, conhecidos e a confirmar.

Foi de imediato possível constatar uma reposição do nível sedimentar. Esta situação fez com que grande parte do espólio do Bugio 2, observado em 2018, em particular as peças de artilharia em bronze, se encontrassem completamente enterrados. Adicionalmente, foi possível constatar que ambos os destroços contemporâneos, o Patrão Lopes e o Rhona, voltaram a estar cobertos de uma extensa camada de bivalves (mexilhão), fenómeno que se encontrava em regressão nos anos anteriores.
Para além dos mergulhos de monitorização realizados nos locais anteriormente identificados, foram ainda realizados mergulhos de verificação de anomalias que surgiram num levantamento com multifeixe realizado em Setembro de 2018, pela Agência Portuguesa do Ambiente (APA), no âmbito Projeto COSMO - Programa de Monitorização da Faixa Costeira de Portugal Continental. Neste levantamento, além dos contextos já mencionados, de Bugio $1 \mathrm{e}$ Bugio 2, é possível observar mais de uma dúzia de anomalias batimétricas. Em três dessas anomalias, das cinco avaliadas, foram detetados contextos arqueológicos, dois provavelmente naufrágios - Bugio 3 e Bugio 4 .

Bugio 3 é caracterizado por uma grande concreção, com cerca de 20 metros de comprimento, coberta na sua maior parte de bivalves (mexilhão). Os vestígios estendem-se com uma orientação nordeste, e embora tudo indique que se trata de um naufrágio, não foi possível detetar nenhum objeto que possibilite a sua identificação. No entanto, encontravam-se visíveis três aspetos que importa realçar. Na zona mais a sul, encontram-se espalhadas, isoladamente ou em pequenos aglomerados, várias dezenas de pelouros de ferro. Na face leste da concreção, e avançando de sul para norte, encontra-se um objeto que aparenta ser uma peça em ferro, mas que se encontra meio tapada pela areia, com o que poderá ser a parte da culatra encastrada na concreção. Avançando sempre em direção a norte, na mesma face leste, surgem vários vestígios de madeira, muito degradada.

O sítio Bugio 4 corresponde a um depósito com mais de meia centena de barricas de madeira, com aros de vime, que transportariam uma substância cinzenta sólida, da qual foram recolhidas amostras para análise, por elementos da DGPC (Figura 9). As características do contexto são marcadamente semelhantes às identificadas no naufrágio Tejo B.

Para além dos alvos detetados na zona do Cachopo Sul, foi realizada a verificação de um outro naufrágio, da época contemporânea, muito bem preservado, que também surgiu no levantamento da APA. Este destroço, no Cachopo Norte, corresponde possivelmente um vapor inglês de meados do século XIX, encontrando-se fora dos canais de navegação da Barra de Lisboa, cerca de 500 metros a sul da fortaleza de São Julião da Barra (Figura 9). 


\section{CONSIDERAÇÕES FINAIS}

Os naufrágios da Barra do Tejo têm um potencial muito significativo, que ultrapassa o contexto regional, apontando para um questionário científico que diz respeito ao estudo da navegação global, que se desenvolveu a partir de inícios do século XV.

Os vestígios em Bugio 2, provavelmente os restos da nau São Francisco Xavier, que ali naufragou em 1625 quando voltava da Índia, permitem antever um contributo importante para a investigação de variadas temáticas, como a construção naval, o equipamento, nomeadamente militar, e as cargas que circulavam entre vários oceanos. A Rota do Cabo foi uma das mais importantes dos séculos XVI e XVII, tendo permitido prolongar e desviar a Rota da Seda por mar até à Europa, aumentando o fluxo de produtos asiáticos, como a especiarias, os têxteis indianos e chineses ou a porcelana chinesa, a uma escala sem precedentes. Esta teve por isso um impacto na cultura e na sociedade a uma escala global. Ter acesso ao Bugio 2 constitui uma oportunidade para estudar os veículos, as mercadorias, as pessoas e a geografia desta rota. Constitui também uma oportunidade para revisitar a historiografia e repensar conceitos sobre esta fase da globalização, que colocou em contacto direto o Atlântico, o Indico e o Pacífico pela primeira vez, oceanos ocupados por povos com experiências muito diversas.

O potencial do Bugio 1 é mais difícil de determinar por agora. No entanto, é óbvia a complementaridade que este sítio pode ter no estudo das dinâmicas de navegação na época moderna. Marcadamente mais recente, este contexto é dominado pela presença de artilharia e várias âncoras em ferro, surgindo igualmente alguns fragmentos de faiança portuguesa e botijas de fabrico peninsular, a par de cabos de piaçaba, utilizada sobretudo a partir do século XVIII e explorada no Brasil. Este sítio poderá por isso anunciar uma ligação ao Atlântico, numa fase para a qual não dispomos de estudos sistemáticos de navios ou naufrágios em Portugal, além dos dois navios da Boa Vista (Bettencourt et al., 2017).

Menor é ainda o conhecimento que temos de Bugio 3 e Bugio 4, sobre os quais não há ainda pistas sobre a cronologia, embora estes materializem de uma forma clara a importância da zona do Bugio enquanto ponto de transição entre a navegação oceânica e fluvial.

Os naufrágios em ferro, Patrão Lopes e Rhona, transportam a região de Lisboa para a navegação no século
XX, enquanto cenário da Primeira Guerra Mundial ou porto estratégico na exploração de recursos minerais em Portugal.

Esta importância científica e patrimonial constitui um desafio para a arqueologia portuguesa, tendo resultado num protocolo de colaboração entre o Município de Cascais, a Marinha e a Faculdade de Ciências Sociais e Humanas da Universidade Nova de Lisboa. Este prevê articular um plano plurianual para o estudo, salvaguarda de valorização dos sítios de época moderna, incluindo ainda uma componente de formação superior.

\section{BIBLIOGRAFIA}

BETTENCOURT,J., FONSECA, C., SILVA, T., CARVALHO, P., COELHO, I. e LOPES, G. (2017) - Os Navios de época Modernos de Lisboa: balanço e perspectivas de investigação. In CAESSA, A., NOZES, C., CAMEIRA, I. e SILVA, R.B. (coord.), I Encontro de Arqueologia de Lisboa: Uma cidade em escavação. Lisboa: CML, CAL, pp. 478-495.

FREIRE, Jorge (2014) - Maritime Cultural Landscape. A New Approach to the Cascais coastline. Journal of Maritime Archaeology, 9 (1), pp. 143-157.

HUTTER, Lucy Maffei (2005) - Navegação nos séculos XVII e XVIII. Rumo: Brasil, São Paulo. São Paulo: Editora da Universidade de São Paulo.

LATOUR, Bruno (2005) - Reassembling the social: an introduction to actor-network theory. Oxford University Press.

MONTEIRO, Alexandre, FREIRE, Jorge, BISCAIA, Flávio, COSTA, Paulo, GAUTHIER-BÉRUBÉ, Marijo, PATACAS, Pedro e PINTO, Sandro (2018) - Notícia preliminar da descoberta de dois naufrágios na entrada do estuário do Tejo. Al-Madan Online, II ${ }^{a}$ Série, n. ${ }^{\circ}$ 22, Tomo 1, pp. 166-17o.

OLIVEIRA, Maurício de (1939) - Allô! Allô! Patrão Lopes. Lisboa, Parceria António Maria Pereira, 2 vols.

ROSA, Gonçalo (2015) - Patrão Lopes. National Geographic, n‥ 177, Dezembro de 2015.

SILVA, Manuel Eugénio da e CARDOSO, Gilherme (2005) - Naufrágios e Acidentes Marítimos no litoral Cascalense, Cascais: Junta de Freguesia, $2^{2}$ edição.

WESTERDAHL, Christer (1992) - The Maritime Cultural Landscape. The International Journal of nautical Archaeology, 21(1), pp. 5-14.

WESTERDAHL, Christer (2011) - The Maritime Cultural Landscapes. In Catsambis, A., Ford, B. Hamilton, D. L. (Eds), The Oxford Handbook of Maritime Archaeology. Oxford University Press, pp. 733-762. 


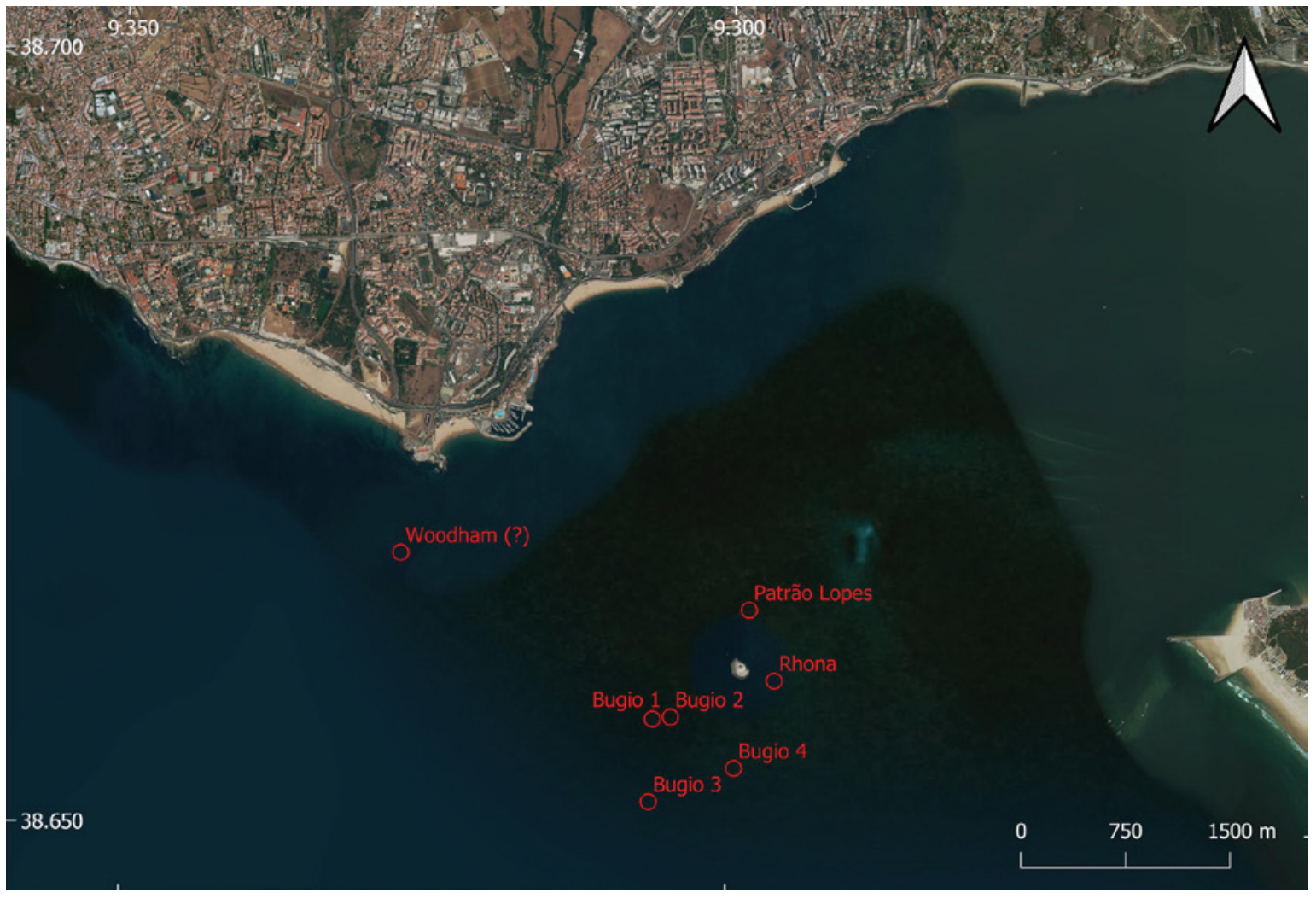

Figura 1 - Localização dos sítios intervencionados na Barra do Tejo em 2018 e 2019 (imagem base: ESRI Satellite).

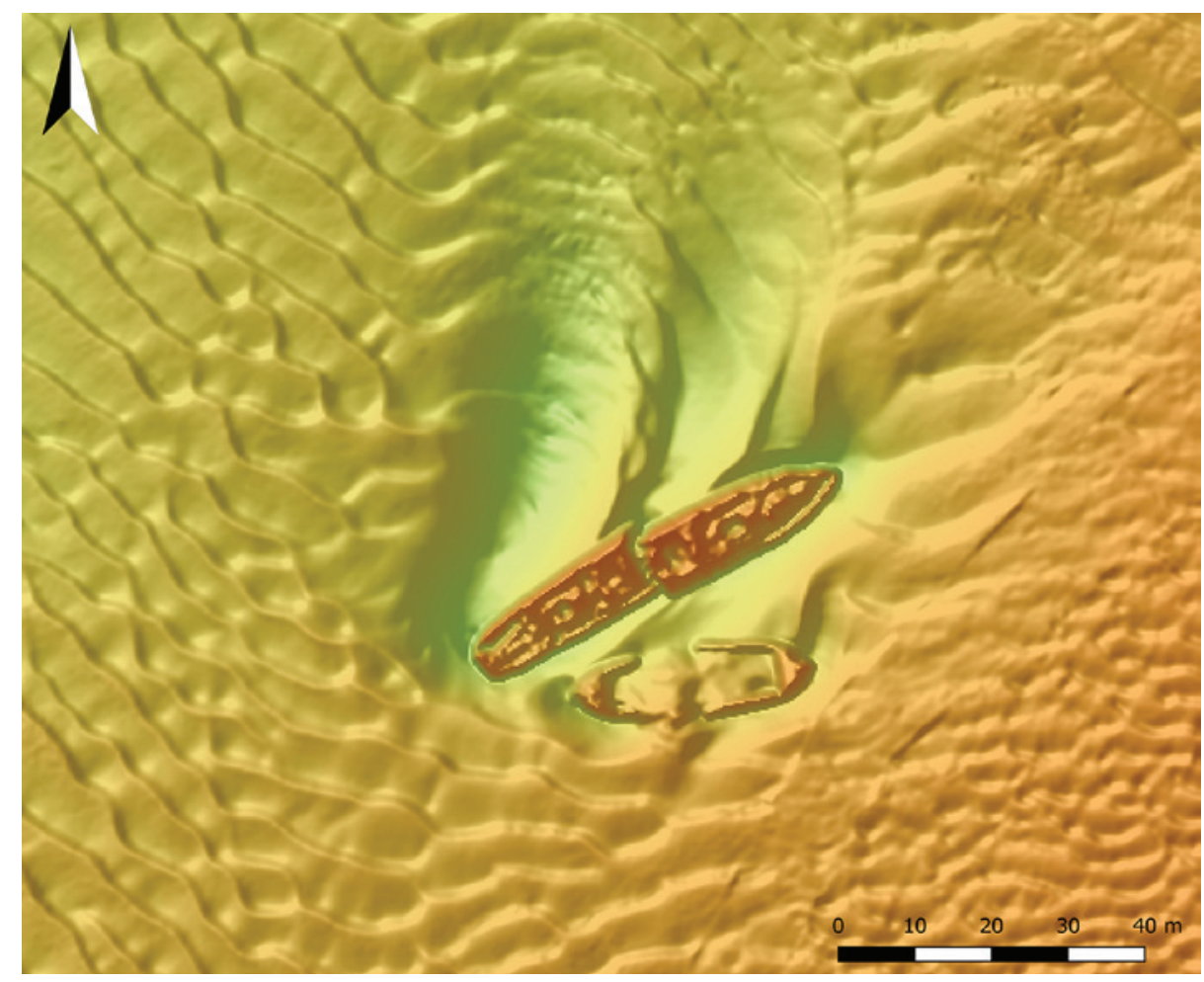

Figura 2 - Modelo batimétrico do Patrão Lopes, efectuado em 2018 (dados: Projeto COSMO - Programa de Monitorização da Faixa Costeira de Portugal Continental, Agência Portuguesa do Ambiente). 


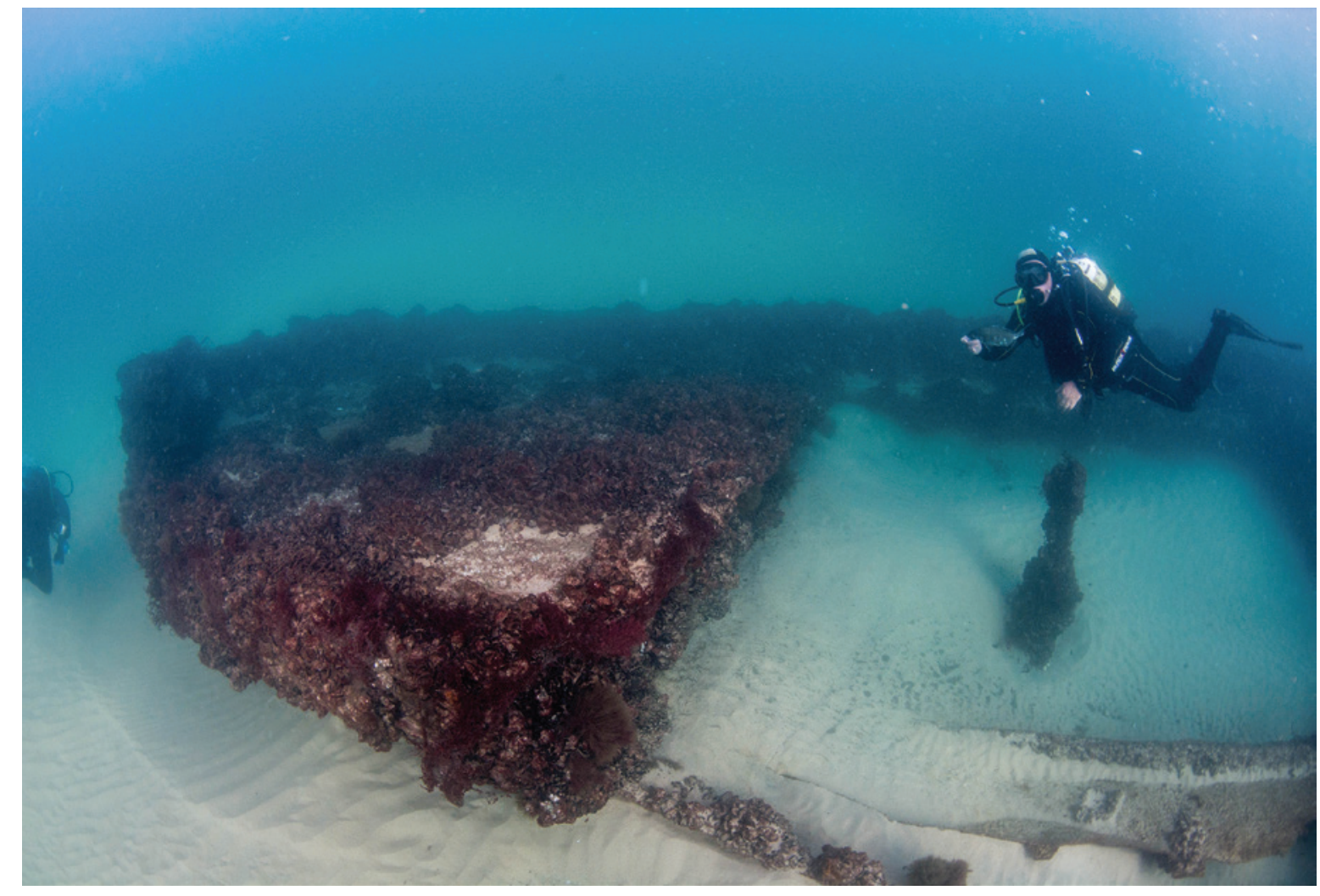

Figura 3 - Vestígios do Rhona, em Agosto de 2018 (foto: Augusto Salgado).

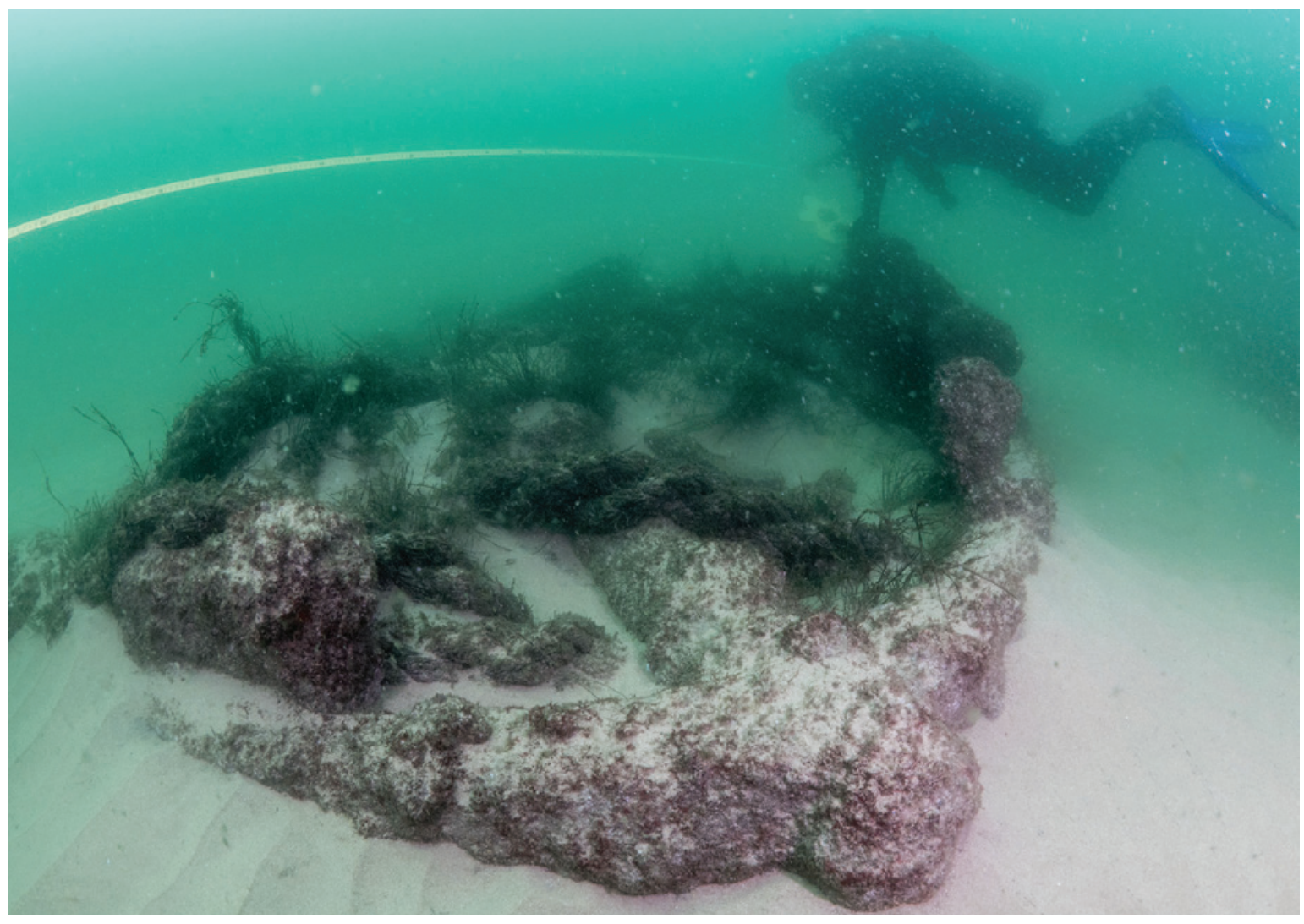

Figura 4-Bugio 1 (foto: Augusto Salgado). 


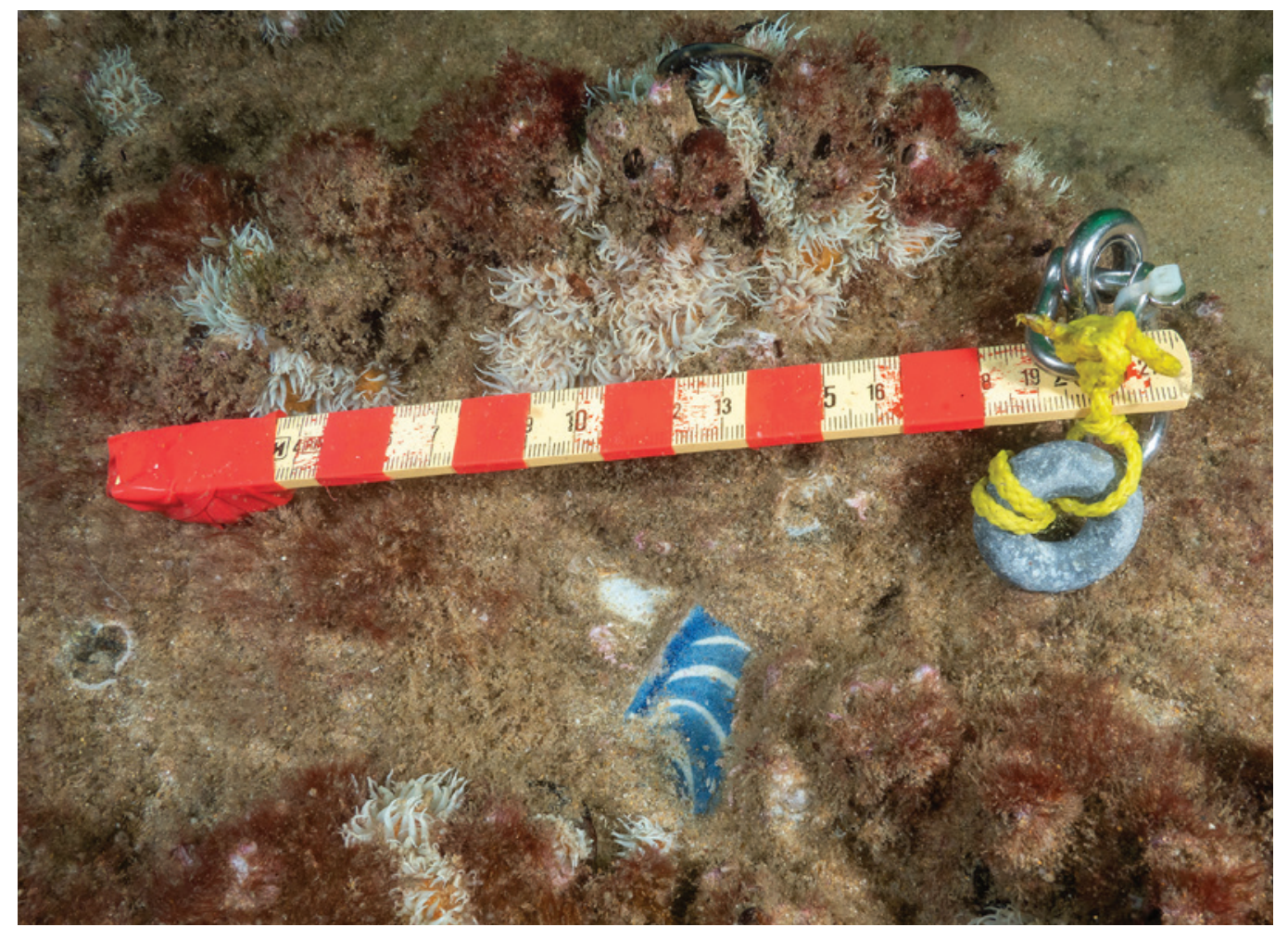

Figura 5 - Fragmento de faiança documentado nas concreções de Bugio 1 (foto: Augusto Salgado).

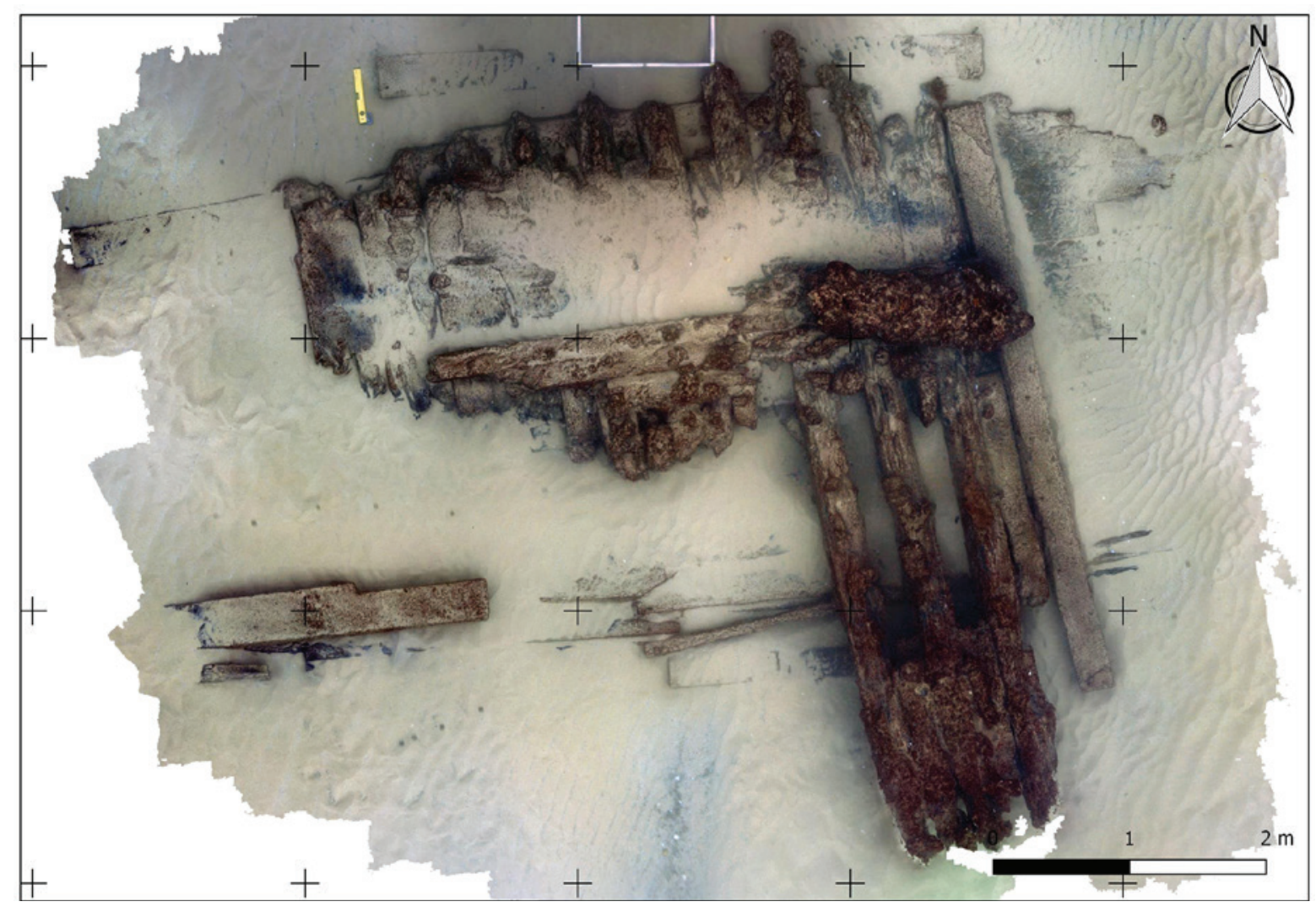

Figura 6 - Área C (ortofotografia: José Bettencourt; norte magnético). 


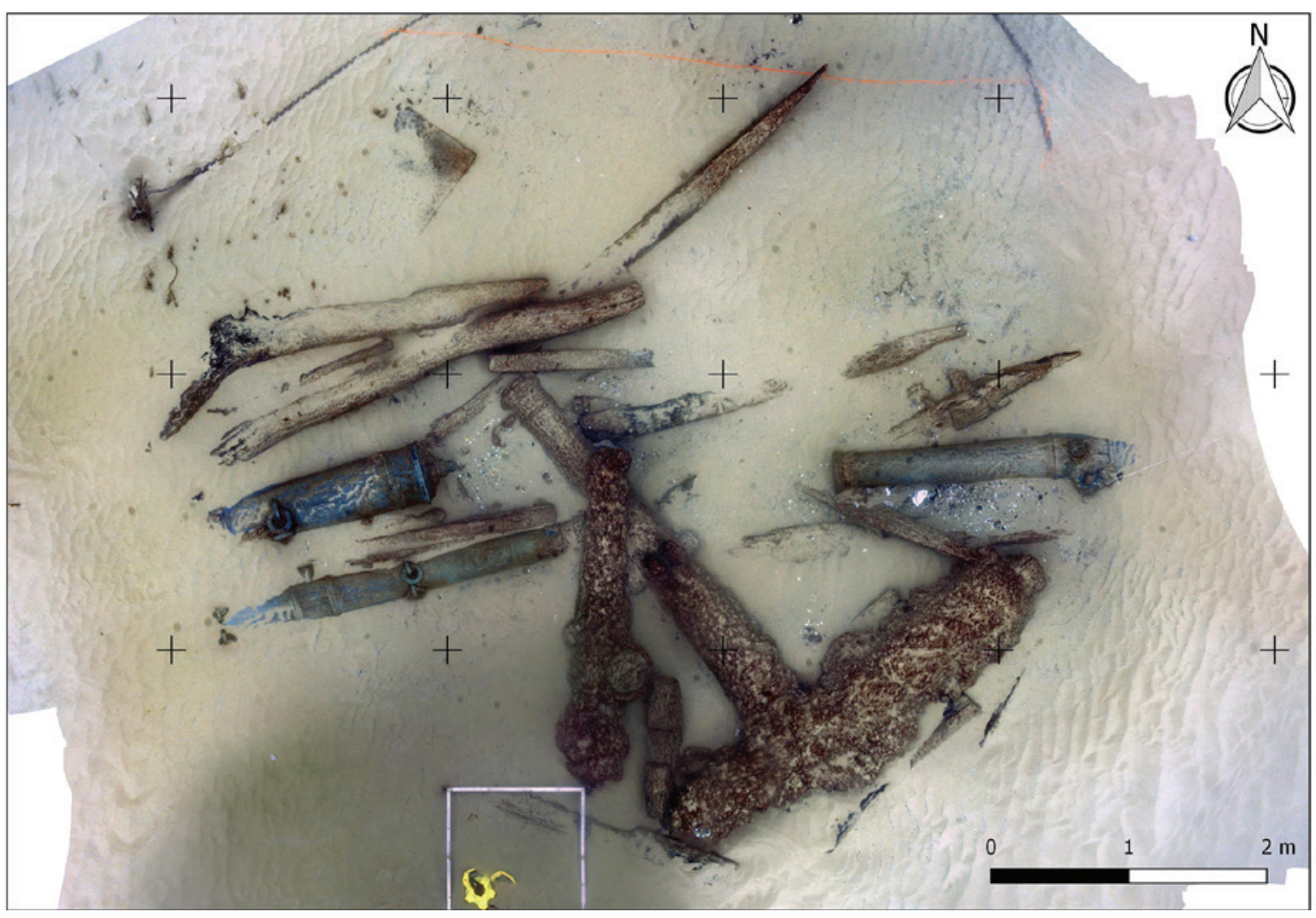

Figura 7- Área B (ortofotografia: José Bettencourt; norte magnético).

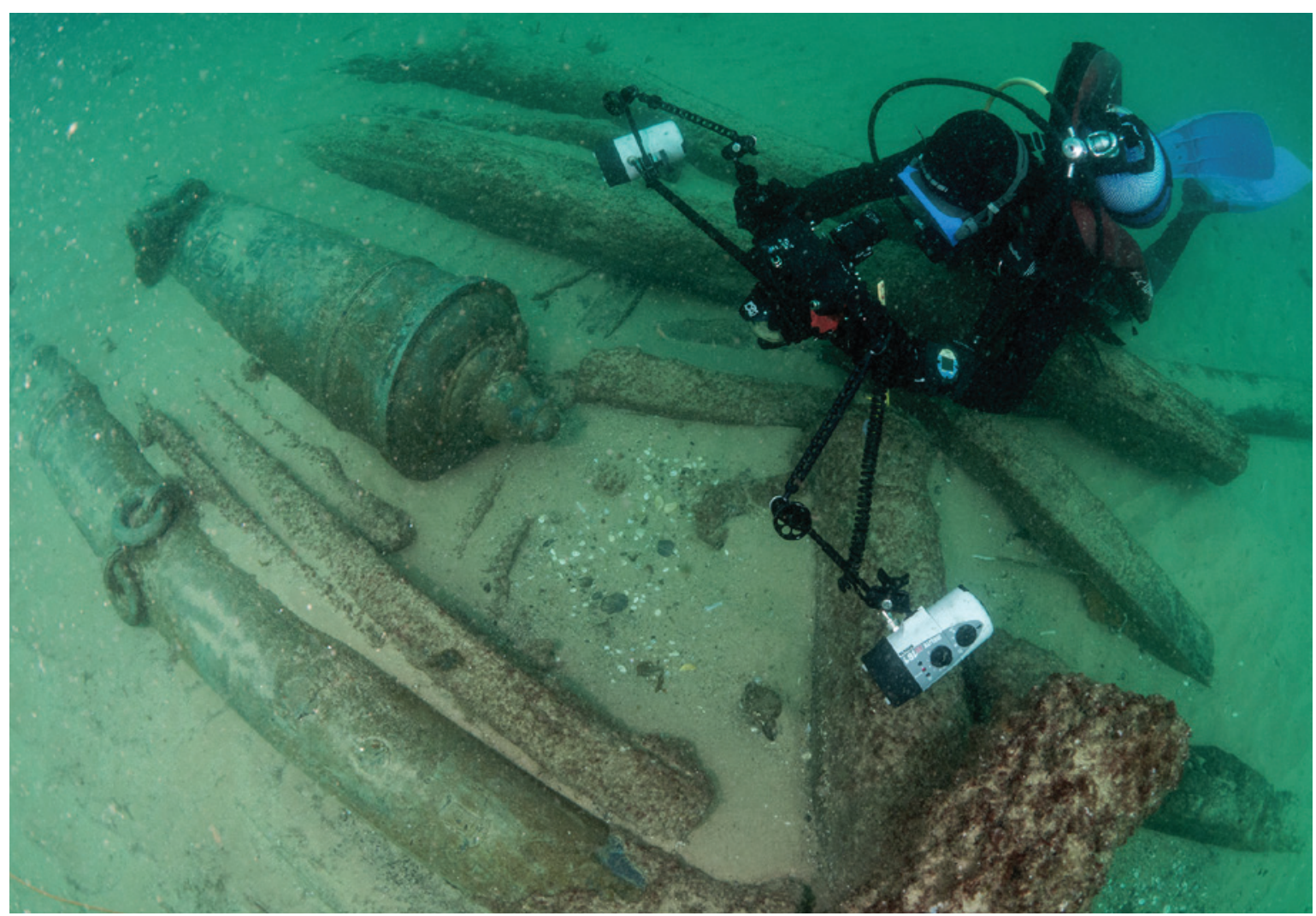

Figura 8 - Conjunto de bocas-de-fogo documentado na Área B (foto: Augusto Salgado). 


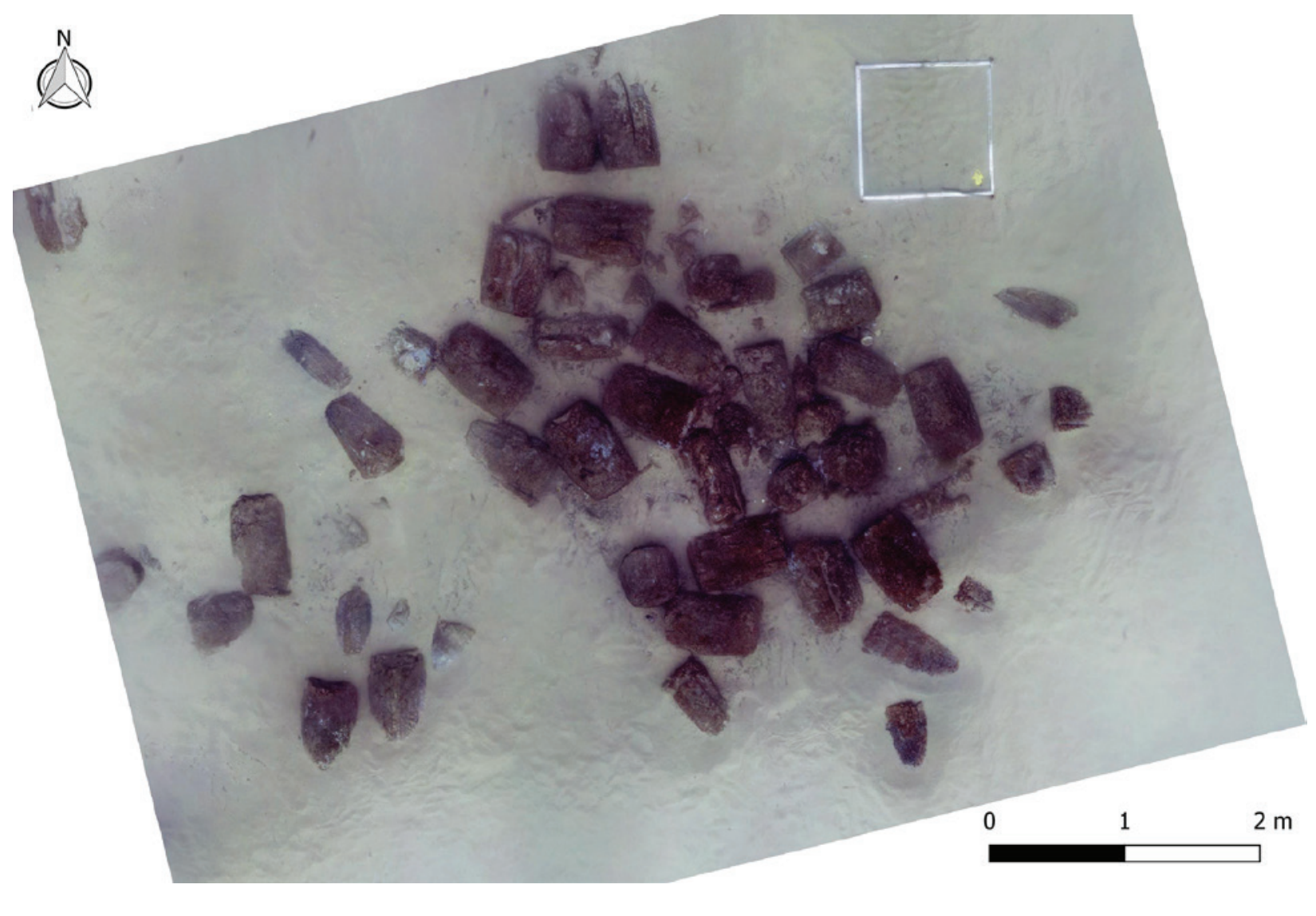

Figura 9-Bugio 4, em 2019 (ortofotografia: José Bettencourt; norte magnético). 



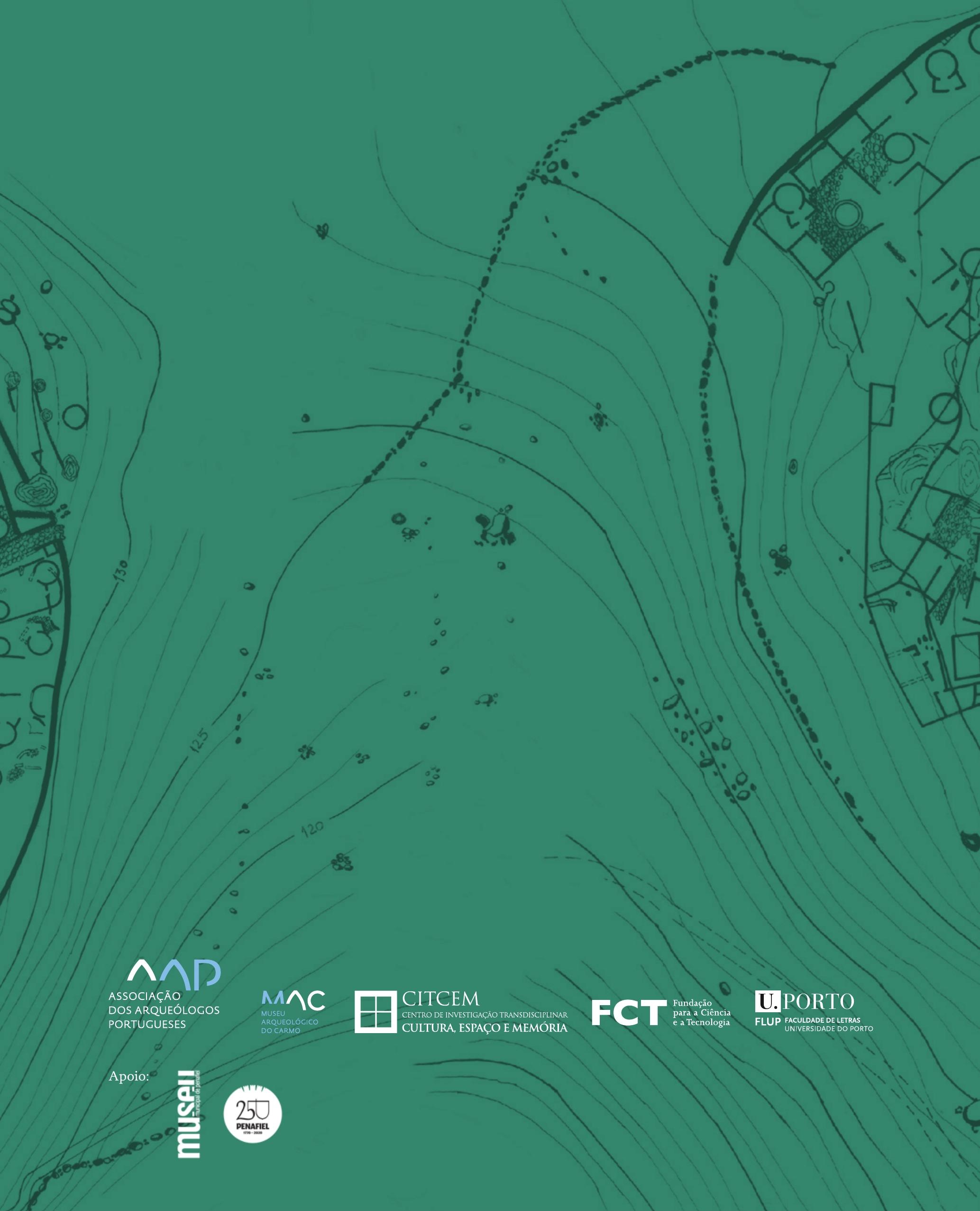

